\title{
Maternal supply of methionine during late pregnancy is associated with changes in immune function and abundance of microRNA and mRNA in Holstein calf polymorphonuclear leukocytes
}

\author{
C. B. Jacometo, ${ }^{*} †$ A. S. Alharthi, † Z. Zhou, $\ddagger$ D. Luchini, $\S$ and J. J. Loor ${ }^{1}$ \\ *Programa de Zootecnia, Facultad de Ciencias Agropecuarias, Universidad de La Salle, 110231, Bogotá DC, Colombia \\ †Mammalian NutriPhysioGenomics, Department of Animal Sciences and Division of Nutritional Sciences, University of Illinois, Urbana 61801 \\ $\ddagger$ Animal and Veterinary Sciences, Clemson University, Clemson, SC 29634 \\ §Adisseo NA, Alpharetta, GA 30022
}

\section{ABSTRACT}

Pregnancy and early life are critical periods during which environmental factors such as nutrition can affect development. Rumen-protected methionine (Met; RPM) supplementation during the prepartum period improves not only performance but immune responses in dairy cows. We investigated the effects of enhanced maternal supply of Met via feeding RPM on whole-blood in vitro lipopolysaccharide (LPS; $0,0.01$, or $5 \mu \mathrm{g} / \mathrm{mL}$ of blood) challenge and targeted microRNA and mRNA abundance in calf blood polymorphonuclear leukocytes (PMNL). Calves ( $\mathrm{n}=12 /$ maternal diet) born to cows fed RPM at $0.08 \%$ of diet dry matter (DM)/d (MET) for the last $21 \pm 2 \mathrm{~d}$ before calving or fed a control diet with no added Met (CON) were used. The PMNL were isolated at birth (before colostrum feeding) and $\mathrm{d}$ 1 (24 h after colostrum intake), 14, 28, and 50 of age. Maternal blood was collected at $-10 \pm 1.3 \mathrm{~d}$ relative to calving. Cows in the MET group had greater DM intake and lower prepartal haptoglobin concentration. In CON cows, haptoglobin was positively correlated with proinflammatory and host-defense mRNA abundance in CON calves. Except for NOS2 and NFE2L2, abundance of $C A S P 8, M P O, Z B P 1$, and $T N F$ was lower at birth in MET calves. Interleukin $1 \beta$ concentration in response to LPS challenge in CON and MET calves was greatest at birth, underscoring the role of this cytokine for lymphocyte activation. Compared with $1 \mathrm{~d}$ of age, the interleukin- $1 \beta$ response to incremental doses of LPS was greater at 14 through $28 \mathrm{~d}$, suggesting that the neonatal calf can mount a robust response to inflammatory stimuli. Greater abundance in CON calves of NOS2, CADM1, and TLR2 coupled with lower $S E L L$ from 1 through $50 \mathrm{~d}$ of age suggested a chronic activation of the PMNL. There was a marked upregula-

Received January 10, 2018.

Accepted May 2, 2018.

${ }^{1}$ Corresponding author: jloor@illinois.edu tion over time of MIR125b, MIR146a, MIR155, and MIR9 in both CON and MET calves, suggesting that these microRNA could affect gene transcription associated with differentiation and inflammatory function in PMNL. Regardless of maternal diet, the gradual downregulation of MIR223 (the most abundant microRNA in PMNL) is in line with the progressive increase over time in the proinflammatory signature of the PMNL. Data revealed the potential for maternal supply of Met during late pregnancy through either greater DM intake or Met to elicit some changes in PMNL function during early postnatal life, partly through changes in mRNA expression encompassing cell adhesion and chemotaxis, oxidative stress, Toll-like receptor signaling, and Met metabolism.

Key words: glutathione, transsulfuration, inflammation, nutritional programming

\section{INTRODUCTION}

Enhancing the supply of Met via feeding with rumenprotected Met (RPM) during the periparturient period increases DMI, which is extremely important for reducing incidence of metabolic disorders around calving (Osorio et al., 2013; Roche et al., 2013). A reduction in proinflammatory status also has been observed in cows fed RPM during the peripartal period (Osorio et al., 2014; Zhou et al., 2016c). All these effects are associated with better milk production, reduced metabolic disorders (ketosis and retained placenta), and better overall liver function and innate immune response (Zhou et al., 2016a).

For calves, understanding the relationship between maternal and neonatal biomarkers of stress and inflammation during the neonatal period could help in devising measures to reduce inflammation and improve health during early life (Bertoni et al., 2009). At birth, calves are exposed to an initial stress that is compounded by additional stresses associated with common husbandry approaches such as weaning; hence, immune challenges 
early in life are an important component of the neonatal period (Ranade et al., 2014). Therefore, manipulation of maternal nutrition to improve health during the neonatal period and reduce the initial stress of birth is of importance (Jacometo et al., 2016).

There have been tremendous advances over the years in our knowledge of the nutritional physiology of the calf (Blum, 2006; Naeem et al., 2012). However, the extent to which prenatal maternal nutrition affects the molecular profiles of inflammatory pathways and polymorphonuclear leukocyte (PMNL) function in the neonatal animal is not well defined. Molecular tools clearly could enhance our understanding of how nutrition regulates basic functions of immune cells during stressful periods (Everts et al., 2005; Moyes et al., 2010). Methionine is one of the limiting AA for the newborn calf, and the supplementation of milk replacers with Met and Lys improved calf performance (Hill et al., 2008). Besides the role of AA in protein synthesis, there are data indicating a benefit of supplementing dietary AA that can affect the regulation of metabolic pathways to sustain the immune response against pathogens (Li et al., 2007).

Maternal circulating AA is reduced around calving (Zhou et al., 2016b), and the effect on calf immunometabolism still needs to be investigated. Recently, an in vitro study with neonatal Holstein calf PMNL demonstrated that the supplementation with Met, choline, or taurine increased homocysteine synthesis, mitigated the inflammatory response, and affected the antioxidant systems, highlighting the important role of these compounds in establishing an adequate immune response during the neonatal period (Abdelmegeid et al., 2017).

Currently, no reports on the effects of maternal supplementation of methyl donors during the dry period have evaluated residual effects on the transcription of genes related to immune function in the calf PMNL. Thus, the specific objective of this study was to evaluate the response to an in vitro whole-blood LPS challenge and profile the expression of $29 \mathrm{mRNA}$ and $5 \mathrm{mi}-$ croRNA related to various biologic processes in PMNL using calves born to cows fed control or RPM diets during the last $21 \pm 2 \mathrm{~d}$ of pregnancy. Results from the same study on blood biomarkers of metabolism, inflammation, and liver function and hepatic transcription of genes associated with metabolic processes and the 1-carbon metabolism have been reported previously (Jacometo et al., 2016, 2017).

\section{MATERIALS AND METHODS}

All procedures for this study were conducted in accordance with a protocol approved by the Institutional
Animal Care and Use Committee of the University of Illinois (protocol no. 13023).

\section{Maternal Treatments}

Details of the experimental design have been published previously (Jacometo et al., 2016). Briefly, 40 multiparous Holstein cows received a common early dry period diet (far-off diet) from -50 to $-22 \mathrm{~d}$ relative to parturition, with low energy and high straw designed to meet and not greatly exceed $100 \%$ of energy requirements. Cows received a higher energy diet from $-21 \pm$ $2 \mathrm{~d}$ until calving day (close-up diet). Calves were born to cows randomly assigned to receive RPM (Smartamine, Adisseo NA, Alpharetta, GA) at $0.08 \%$ of diet DM/d (MET; $\mathrm{n}=20 ; \sim 2.9$ :1 Lys:Met) or no supplemental Met (CON; $\mathrm{n}=20 ; \sim 3.35: 1$ Lys:Met) during the close-up period (Supplemental Table S1; https:// doi.org/10.3168/jds.2018-14428). The Met supplement was top-dressed on the TMR. Ingredient and chemical composition of the diets is reported in Supplemental Table S1 (https://doi.org/10.3168/jds.2018-14428). Cow BW $(773 \pm 11 \mathrm{~kg})$ and BCS $(3.51 \pm 0.05)$ did not differ. After birth, calves were fed a common diet and managed similarly.

\section{Animal Management and Calf Enrollment Criteria}

Complete details of these methods have been reported elsewhere (Jacometo et al., 2016). Briefly, during the dry period, cows were housed in a ventilated, sandbedded freestall barn. Diets were fed for ad libitum intake as a TMR once daily using an individual gate feeding system (American Calan, Northwood, NH), and DMI was recorded daily. Colostrum volume was recorded and IgG content was estimated immediately based on specific gravity with a bovine colostrometer (cat. no. C10978N; Nasco, Fort Atkinson, WI). Calves were fed fresh colostrum from their respective dams within $6 \mathrm{~h}$ after birth. If voluntary colostrum intake had not reached the required $3.8 \mathrm{~L}$, calves were force-fed via esophageal tube. Colostrum yield $(7.6 \mathrm{~kg}), \mathrm{IgG}$ content $(78.7 \mathrm{mg} / \mathrm{dL})$, total free AA concentration $(301 \mu / \mathrm{mL})$, and Met concentration ( $0.29 \%$ of total AA) did not differ (Jacometo et al., 2016, 2017).

Calf enrollment criteria, management after birth, and housing were described in detail elsewhere (Jacometo et al., 2016). Briefly, calves were housed in individual outdoor hutches bedded with straw, fed twice daily with a milk replacer (28.5\% CP, $15 \%$ fat; Advance Excelerate, Milk Specialties, Carpentersville, IL; $520 \mathrm{~g} / \mathrm{d}$ from 1 to $10 \mathrm{~d}$ of age, $680 \mathrm{~g} / \mathrm{d}$ from 11 to $20 \mathrm{~d}$ of age, $840 \mathrm{~g} / \mathrm{d}$ from 21 to $35 \mathrm{~d}$ of age, and $420 \mathrm{~g} / \mathrm{d}$ from 36 to $42 \mathrm{~d}$ of age in a single feeding), and had ad libitum access to a 
starter grain mix (19.9\% CP, $13.5 \%$ NDF). Growth performance, including BW and withers height, is reported in Supplemental Table S2 (https://doi.org/10.3168/jds .2018-14428). Calves were weaned at $42 \mathrm{~d}$ of age. All calves remained clinically healthy during the study.

\section{Sample Collection}

Calves were born to cows randomly assigned to receive RPM (MET, $\mathrm{n}=20$ ) or no supplemental Met $(\mathrm{CON}, \mathrm{n}=20)$ during the last $21 \pm 2 \mathrm{~d}$ until calving day. Blood samples were collected from calves that did not receive liver biopsy ( $\mathrm{n}=12$ /group) from the jugular vein using 20-gauge BD Vacutainer needles (Becton Dickinson, Franklin Lakes, NJ) before receiving colostrum (baseline), $24 \mathrm{~h}$ after receiving colostrum, and 14, 28 , and $50 \mathrm{~d}$ after birth. At each time point, a total of $120 \mathrm{~mL}$ of blood was collected in Vacutainer tubes (Becton Dickinson) containing lithium heparin and in tubes containing a solution of trisodium citrate, citric acid, and dextrose $(100 \mathrm{~mL})$. Sample processing was as reported in detail previously (Jacometo et al., 2015).

\section{Whole-Blood In Vitro LPS Challenge}

The blood collected in lithium heparin tubes remained in a warm water bath $\left(38-39^{\circ} \mathrm{C}\right)$ until LPS challenge. Briefly, $980 \mu \mathrm{L}$ of homogenized whole blood in duplicate was transferred to endotoxin-free 2-mL tubes and an Escherichia coli LPS solution (strain 0111:B4, cat. no. L4391, Sigma-Aldrich, St. Louis, MO) was added. As in our previous research (Vailati-Riboni et al., 2017), 3 doses were tested: control (0 $\mu \mathrm{g}$ of LPS/mL of blood), $0.01 \mu \mathrm{g}$ of LPS/mL of blood, and $5 \mu \mathrm{g}$ of LPS/ $\mathrm{mL}$ of blood. Samples were homogenized and incubated in a rotating water bath $\left(3.5 \mathrm{~h}, 38^{\circ} \mathrm{C}\right)$ and centrifuged $\left(4,000 \times g\right.$ for $\left.15 \mathrm{~min}, 4^{\circ} \mathrm{C}\right)$, and then the supernatant was harvested and stored at $-80^{\circ} \mathrm{C}$ until analysis. Bovine IL-1 $\beta$ plasma concentrations were determined by a colorimetric sandwich ELISA using a bovine screening set (Thermo Fisher Scientific, Waltham, MA).

\section{PMNL Isolation and Viability Analysis}

Complete details of PMNL isolation and viability analysis are described elsewhere (Jacometo et al., 2015). Briefly, neutrophils were isolated from whole blood $(120 \mathrm{~mL})$ collected in Vacutainer tubes containing a solution of trisodium citrate, citric acid, and dextrose within $1 \mathrm{~h}$ of sample collection. An aliquot $(20 \mu \mathrm{L})$ obtained during the PMNL isolation process was used for PMNL quantification and viability using a granulocyte primary antibody (CH138A, Veterinary Microbiology and Pathology, Washington State University, Pullman, WA) followed by a second antibody (goat anti-mouse IgM, Human ads-PE, Southern Biotech, Birmingham, AL). Cells were fixed with $150 \mu \mathrm{L}$ of $4 \%$ paraformaldehyde (Sigma-Aldrich) and preserved at $4^{\circ} \mathrm{C}$ until flow cytometry reading (LSR II, Becton Dickinson). This procedure was performed to ensure that samples were of high quality. All samples harvested and used for analysis contained more than $90 \%$ neutrophils and had at least $90 \%$ viability.

\section{mRNA and microRNA Isolation}

All procedures were reported previously (Jacometo et al., 2015, 2016). Briefly, PMNL total RNA extraction was performed with the miRNeasy kit (Qiagen, Hilden, Germany) following the manufacturer's protocols. Samples were treated on-column with DNaseI (Qiagen), quantification was performed using the NanoDrop ND-1000 (NanoDrop Technologies, Rockland, DE), and RNA quality was measured using an Agilent 2100 bioanalyzer (Agilent, Santa Clara, CA).

\section{Quantitative PCR and Design and Evaluation of Primers}

Reagents and methods for mRNA and microRNA quantitative PCR were previously reported (Jacometo et al., 2015, 2016). The selected target mRNA and microRNA are described in Table 1. For this study, golgin A5 (GOLGA5), single-strand-selective monofunctional uracil-DNA glycosylase 1 (SMUG1), and oxysterol binding protein like 2 (OSBPL2) were used as internal control genes (Jacometo et al., 2015), and their geometric mean was used to normalize the expression data. Primer sequences, sequencing of PCR products, and reverse-transcription PCR performance can be found in Supplemental Tables S3, S4, S5, S6, and S7 (https:// doi.org/10.3168/jds.2018-14428).

\section{Maternal Plasma Biomarkers}

The complete analyses of plasma biomarkers in cows from which calves in this study came have been published previously (Zhou et al., 2016b). For the present study, only samples collected from cows at $-10 \mathrm{~d}$ from expected parturition were used for statistical analysis. Briefly, maternal blood was sampled from the coccygeal vein at $-10 \mathrm{~d}$ relative to expected parturition before the morning feeding (on average $-10.9 \pm 1.3 \mathrm{~d}$ relative to actual calving date). The objective of this study was to establish differences in plasma biomarkers close to parturition and, in particular, correlations between 
inflammation-related biomarkers in the cows and the expression of mRNA in the PMNL of calves at birth.

\section{Statistical Analysis}

Data were analyzed with the Proc MIXED procedure of SAS 9.4 (SAS Institute Inc., Cary, NC). Data at birth were analyzed independently of other time points. Data of PMNL mRNA abundance at $24 \mathrm{~h}$ and 14,28 , and $50 \mathrm{~d}$ were analyzed with a repeated measures model including treatment, day, and their interaction as fixed effects. Data of LPS challenge were analyzed in a similar fashion except for the inclusion of the 3-way interaction of treatment $x$ day and LPS dose. Random effect was calf within diet. The exponential correlation covariance structure for repeated measures was used for analysis of gene expression and LPS challenge data. Data were $\log _{2}$-scale transformed if needed to comply with normal distribution of residuals and subsequently back-transformed for ease of interpretation. The mRNA abundance $P$-values were adjusted using Benjamini and Hochberg's false discovery rate. The Kenward-Roger statement was used for computing the denominator degrees of freedom. Pearson correlations were calculated between statistically significant inflammation-related biomarkers in cow blood at $-10.9 \pm 1.3$ relative to actual calving date and mRNA expression in the respective calf PMNL at birth (i.e., CON cows and CON calves; MET cows and MET calves). In addition, Pearson correlations were calculated between plasma concentration of IL-1 $\beta$ at birth and mRNA expression in the PMNL at birth in

Table 1. Genes and microRNA selected for transcript profiling in calf blood polymorphonuclear leukocytes classified according to their primary biological function

\begin{tabular}{|c|c|}
\hline Gene name & Symbol \\
\hline \multicolumn{2}{|l|}{ Cell adhesion and chemotaxis } \\
\hline Selectin L & $S E L L$ \\
\hline Cell adhesion molecule 1 & $C A D M 1$ \\
\hline Lymphocyte cytosolic protein 1 (L-plastin) & $L C P 1$ \\
\hline Caspase 8 & CASP8 \\
\hline Cytochrome $b-245, \alpha$ polypeptide & $C Y B A$ \\
\hline Z-DNA binding protein 1 & $Z B P 1$ \\
\hline C-X-X motif chemokine receptor 2 & $C X C R 2$ \\
\hline \multicolumn{2}{|l|}{ Oxidative stress } \\
\hline Myeloperoxidase & $M P O$ \\
\hline Nitric oxide synthase 2 , inducible & NOS2 \\
\hline Superoxide dismutase 1 , soluble & SOD1 \\
\hline Superoxide dismutase 2 , mitochondrial & SOD2 \\
\hline Nuclear factor (erythroid-derived 2)-like 2 & NFE2L2 \\
\hline \multicolumn{2}{|l|}{ Toll-like receptor pathway } \\
\hline Toll-like receptor 2 & TLR2 \\
\hline Toll-like receptor 4 & $T L R_{4}$ \\
\hline Myeloid differentiation primary response gene (88) & MYD88 \\
\hline Interleukin-1 receptor-associated kinase 1 & $\operatorname{IRAK1}$ \\
\hline TNF receptor-associated factor 6 & TRAF6 \\
\hline Nuclear factor of kappa light polypeptide gene enhancer in B-cells 1 & NFKB1 \\
\hline Nuclear factor of kappa light polypeptide gene enhancer in B-cells inhibitor, $\alpha$ & NFKBIA \\
\hline Tumor necrosis factor- $\alpha$ & $T N F$ \\
\hline Interleukin $1, \beta$ & $I L 1 B$ \\
\hline Signaling lymphocyte activation molecules (SLAM) family member 7 & SLAMFY \\
\hline \multicolumn{2}{|l|}{ Met cycle } \\
\hline Cystathionine gamma-lyase & $\mathrm{CTH}$ \\
\hline Cystathionine- $\beta$-synthase & $C B S$ \\
\hline Adenosylhomocysteinase & $S A H H$ \\
\hline \multicolumn{2}{|l|}{ Glutathione metabolism } \\
\hline Glutamate-cysteine ligase, catalytic subunit & $G C L C$ \\
\hline Glutathione synthetase & $G S S$ \\
\hline Glutathione reductase & $G S R$ \\
\hline \multirow{2}{*}{\multicolumn{2}{|c|}{ microRNA }} \\
\hline & \\
\hline MicroRNA mir-125b & MIR125b \\
\hline MicroRNA mir-146a & MIR146a \\
\hline MicroRNA mir-155 & MIR155 \\
\hline MicroRNA mir-223 & MIR223 \\
\hline MicroRNA mir-9 & MIR9 \\
\hline
\end{tabular}


Table 2. Performance and blood biomarkers in the prepartum period in cows fed a control diet (CON) or CON supplemented with rumenprotected Met (MET) during the last $21 \mathrm{~d}$ prepartum

\begin{tabular}{|c|c|c|c|c|}
\hline \multirow[b]{2}{*}{ Item $^{1}$} & \multicolumn{2}{|c|}{ Treatment } & \multirow[b]{2}{*}{ SEM } & \multirow[b]{2}{*}{$P$-value } \\
\hline & $\mathrm{CON}$ & MET & & \\
\hline$\overline{\mathrm{BW}, \mathrm{kg}}$ & 767 & 799 & 17.9 & 0.22 \\
\hline BCS & 3.47 & 3.60 & 0.06 & 0.14 \\
\hline DMI, $\mathrm{kg} / \mathrm{d}$ & 12.9 & 15.0 & 0.48 & 0.004 \\
\hline \multicolumn{5}{|l|}{ Plasma } \\
\hline \multicolumn{5}{|l|}{ Metabolism } \\
\hline Fatty acids & 0.278 & 0.201 & 0.04 & 0.14 \\
\hline Glucose & 4.36 & 4.52 & 0.05 & 0.03 \\
\hline Hydroxybutyrate & 0.502 & 0.487 & 0.02 & 0.71 \\
\hline Urea & 4.87 & 4.85 & 0.16 & 0.95 \\
\hline Creatinine & 94 & 93 & 1.8 & 0.72 \\
\hline \multicolumn{5}{|l|}{ Inflammation } \\
\hline Albumin & 35.5 & 35.9 & 0.32 & 0.40 \\
\hline Ceruloplasmin & 2.12 & 2.03 & 0.08 & 0.47 \\
\hline Haptoglobin & 0.321 & 0.214 & 0.03 & 0.04 \\
\hline IL-1 $\beta$ & 5.53 & 4.99 & 0.78 & 0.62 \\
\hline Myeloperoxidase & 373 & 392 & 19 & 0.48 \\
\hline \multicolumn{5}{|l|}{ Oxidative stress } \\
\hline ROM & 11.4 & 11.5 & 0.40 & 0.87 \\
\hline FRAP & 132 & 116 & 11 & 0.32 \\
\hline Paraoxonase & 82 & 86 & 2.5 & 0.31 \\
\hline \multicolumn{5}{|l|}{ Liver function } \\
\hline Cholesterol & 2.67 & 2.70 & 0.09 & 0.84 \\
\hline GGT & 21.8 & 20.1 & 1.20 & 0.34 \\
\hline $\mathrm{AST}$ & 78.4 & 70.8 & 3.55 & 0.13 \\
\hline Bilirubin & 1.44 & 0.78 & 0.23 & 0.05 \\
\hline
\end{tabular}

${ }^{1} \mathrm{ROM}=$ reactive oxygen metabolites; $\mathrm{FRAP}=$ ferric reducing ability of plasma; GGT = gamma-glutamyl transferase; and AST = aspartate aminotransferase.

the respective calf groups. Statistical significance was declared at $P \leq 0.05$.

\section{RESULTS}

\section{Maternal Concentrations of Biomarkers}

Despite a lack of effect of Met on prepartal BCS and $\mathrm{BW}$, cows in the MET group had greater $(P<0.05)$ DMI (Table 2). Among all biomarkers measured, cows in MET had greater $(P=0.03)$ glucose concentration and lower $(P \leq 0.05)$ haptoglobin and bilirubin. Concentrations of other biomarkers did not differ $(P$ $>0.05)$.

\section{Whole-Blood In Vitro LPS Challenge}

Regardless of dose, no overall maternal treatment effect was observed $(P>0.05)$ for IL-1 $\beta$ concentrations before or after the in vitro LPS challenge. There was a dose $\times$ treatment and a dose $\times$ day effect $(P<$ 0.05; Figure $1 \mathrm{~A}-\mathrm{C})$. In the former, the overall basal (nonstimulated) concentrations of IL-1 $\beta$ were greater for CON calves compared with MET calves, and each increment of LPS dose resulted in a greater response in IL-1 $\beta$ concentration. The dose $\times$ day effect was due primarily to the greater response in IL- $1 \beta$ with each increment of LPS in samples harvested at birth compared with other time points. The greatest response in IL-1 $\beta$ at the highest dose was detected in samples harvested at $28 \mathrm{~d}$ of age compared with 1, 14, and $50 \mathrm{~d}$ of age Figure 1B). The response to the intermediate dose of LPS was greater at 14,28 , and $50 \mathrm{~d}$ of age compared with $1 \mathrm{~d}$ of age.

\section{PMNL mRNA Abundance}

Cell Adhesion and Chemotaxis. At birth, MET calves had lower $(P<0.05) C A S P 8$ and ZBP1 abundance (Table 3). Enhanced maternal supply of Met increased $(P=0.033)$ overall SELL abundance and decreased $(P=0.021)$ CADM1 abundance. A treatment $\times$ day interaction $(P<0.05)$ was observed for the abundance of CADM1, ZBP1, and CXCR2 (Table 4). At $24 \mathrm{~h}$ after colostrum intake, MET calves had greater abundance of $C X C R 2$ (treatment $\times$ day, $P<0.05$ ). At d 14, CADM1 and CXCR2 had lower abundance $(P=$ 0.021 ) in MET calves (Table 4). At d 50, MET calves had higher $Z B P 1$ abundance.

Regardless of maternal diet, an effect of day was detected for all genes. Abundance of CASP8 increased markedly $(P<0.001)$ from d 28 to d 50 (Table 4$)$, being approximately 2 -fold higher at $\mathrm{d} 50$ than at $24 \mathrm{~h}$ after colostrum intake. A similar trend was found for $L C P 1, C Y B A$ and $C A D M 1$ - a gradual decrease after $24 \mathrm{~h}$ and then an increase in the postweaning period $(P<0.001 ;$ Table 4$)$. Abundance of $Z B P 1$ increased markedly from 14 to $28 \mathrm{~d}$ of age $(P<0.001)$, whereas $S E L L$ and $C X C R 2$ decreased markedly $(P<0.001)$.

Oxidative Stress. At birth, MET calves had higher NOS2 $(P<0.001)$ and NFE2L2 $(P=0.003)$ abundance, whereas $M P O$ was lower $(P=0.002$; Table 3$)$. However, enhancing the supply of Met led to lower $(P$ $=0.032)$ NOS2 abundance from $24 \mathrm{~h}$ after colostrum intake through $50 \mathrm{~d}$ of age (Table 4). The abundance of all genes related to oxidative stress changed over time $(P<0.001)$. Abundance of SOD1 and NOS2 increased from $24 \mathrm{~h}$ through the postweaning period. Abundance of $M P O$ increased markedly at $50 \mathrm{~d}$ of age, and SOD2 and NFE2L2 had a higher abundance at $24 \mathrm{~h}$ and then decreased until $50 \mathrm{~d}$ of age (Table 4).

Proinflammatory Pathway. At birth, there was a maternal $\mathrm{T}$ effect only for TNF, where MET calves had lower $(P=0.007)$ abundance (Table 3$)$. From 24 $\mathrm{h}$ after colostrum intake through $50 \mathrm{~d}$ of age, enhanced supply of the pregnant cow with Met resulted in lower TLR2 $(P=0.018)$ and SLAMFr $(P=0.022)$ abun- 


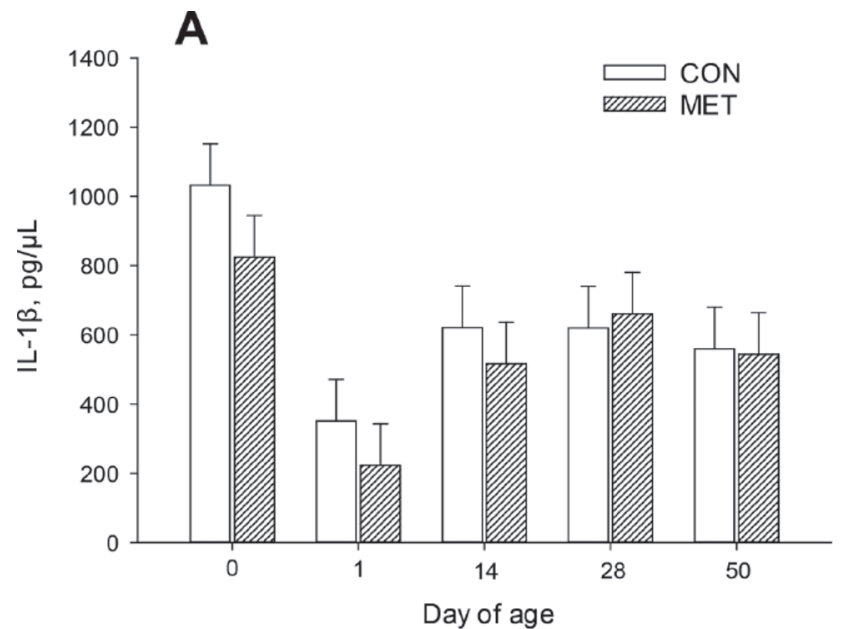

B
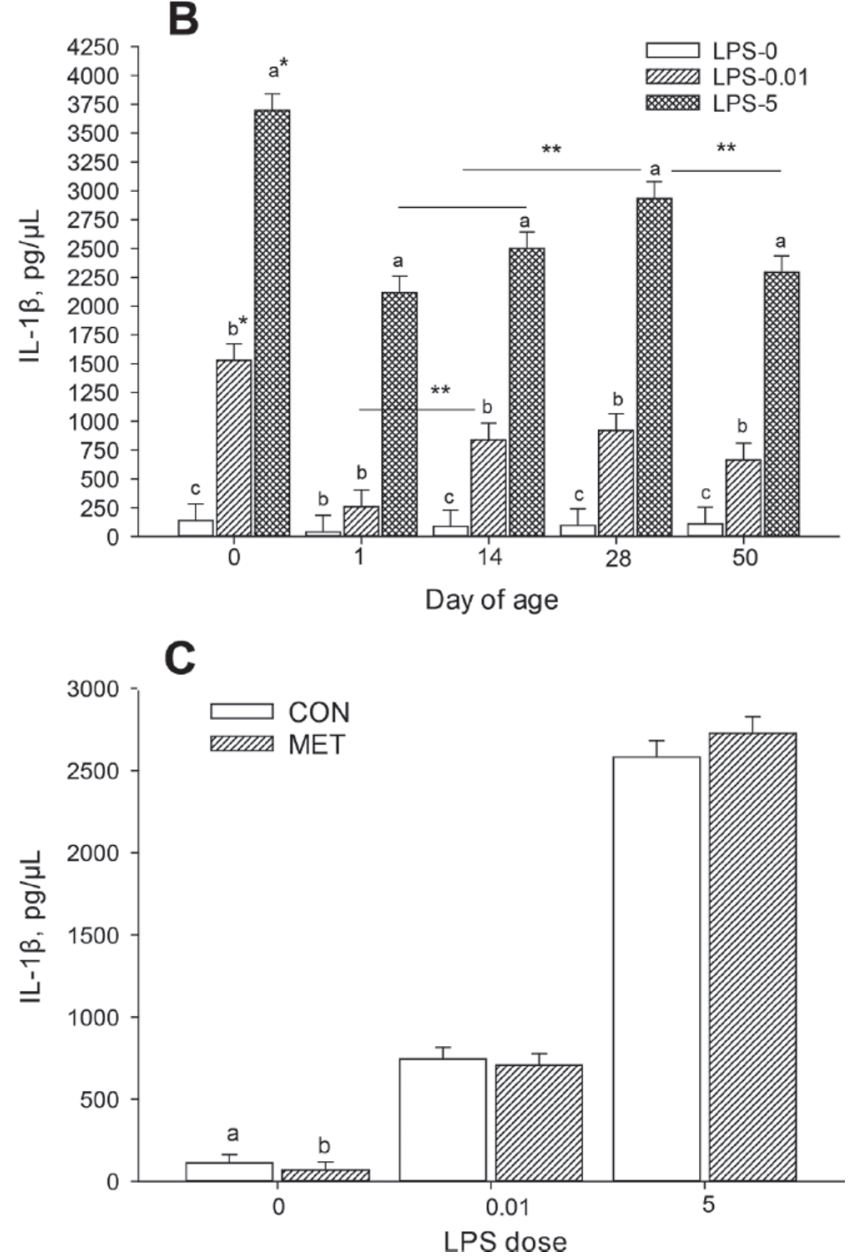

Figure 1. Interleukin $1 \beta$ concentrations in response to LPS challenge $(0,0.01$, or $5 \mu \mathrm{g} / \mathrm{mL})$ of whole blood from calves born to dams fed a control diet (CON) or CON supplemented with rumen-protected Met (MET) during the last $21 \mathrm{~d}$ prepartum. (A) Time by maternal treatment response $(P=0.28)$. (B) Time by dose of LPS response regardless of maternal treatment (CON or MET; $P=0.004)$. (C) Dose by treatment response $(P=0.014)$. Means with different letters $(\mathrm{a}-\mathrm{c})$ differ at a given dose $(\mathrm{C})$ and at a given dose and day of age (B). *Means differ $(P<0.05)$ at birth. ${ }^{* *}$ Means for a given dose of LPS differ $(P<0.05)$ between days. Error bars represent SEM. dance (Table 4). Also, a treatment $\times$ day interaction was observed for TLR2, TLR4, and SLAMFr $(P<$ 0.05). Both TLR2 and TLR4 abundance was lower in MET calves at $14 \mathrm{~d}$ of age. The MET calves had lower $S L A M F$ r abundance $24 \mathrm{~h}$ after colostrum intake and at $50 \mathrm{~d}$ of age (Table 4). Except for TRAF6, the abundance of all evaluated genes from this pathway changed over time $(P<0.001)$. The abundance of IRAK1, $N F K B, T N F, I L 1 B$, and SLAMF' increased over time, whereas the abundance of TLR2, TLR4, MYD88, and NFKBIA decreased at 14 through $50 \mathrm{~d}$, with the lowest abundance at $28 \mathrm{~d}$ of age (Table 4 ).

Methionine Metabolism. At birth, MET calves had higher $C T H(P<0.001)$ and $C B S(P=0.007)$ abundance (Table 3). Despite lower abundance of $C T H$ $(P=0.002)$ in MET calves at $24 \mathrm{~h}$ postcolostrum, abundance increased markedly at subsequent times in those calves, leading to an overall greater $C T H$ (Table 4). The opposite response was observed with the abundance of $S A H H(P=0.019)$ in MET calves. A treatment $\times$ day interaction $(P<0.05)$ was observed for $C B S$ and $S A H H$ abundance (Table 4).

Glutathione Metabolism. At birth, MET calves had lower $(P=0.009)$ GSR abundance (Table 3). Enhanced supply of Met led to a treatment $\times$ day interaction $(P<0.05)$ for the abundance of GSR primarily due to greater abundance at $50 \mathrm{~d}$ of age (Table 4). Regardless of maternal treatment, $G C L C$ and $G S S$ abundance increased gradually over time, with a peak at $50 \mathrm{~d}$ of age $(P<0.001)$. Abundance of $G P X 1$ peaked at $24 \mathrm{~h}$ after colostrum intake regardless of maternal treatment, followed by a gradual decrease and then a marked increase from $28 \mathrm{~d}$ to $50 \mathrm{~d}$ of age $(P<0.001$; Table 4).

MicroRNA. Enhancing the maternal supply of Met did not affect the abundance of the selected microRNA $(P>0.05$; Tables 2 and 3). Except for miR-223, there was an increase in abundance over time for MIR125b, MIR146a, MIR155, and MIR9 $(P<0.001$; Table 3).

\section{Associations Between Plasma Cow Prepartal Haptoglobin and PMNL mRNA Abundance at Birth}

Significant positive correlations $(P \leq 0.05)$ among plasma haptoglobin at $-10 \mathrm{~d}$ prepartum in CON cows and PMNL expression of their calves at birth were detected for several mRNA associated with cell adhesion, chemotaxis and oxidative stress, Toll-like receptor (TLR) signaling, and Met metabolism (Table 5). The only negative correlations in CON cows and their calves were detected for $S L A M F$ 7 and $C B S$. In the MET cows, however, the only significant correlations were negative and between haptoglobin and the abundance of $N F K$ $B I A$ and GPX1 (Table 5). 
Table 3. Messenger RNA expression at birth in polymorphonuclear leukocytes of genes related to cell adhesion and chemotaxis, oxidative stress, Toll-like receptor (TLR) pathway, Met metabolism, glutathione pathway, and microRNA in calves born to dams fed a control diet (CON) or CON supplemented with rumen-protected Met (MET) during the last $21 \mathrm{~d}$ prepartum

\begin{tabular}{|c|c|c|c|c|}
\hline \multirow[b]{2}{*}{ Gene } & \multicolumn{2}{|c|}{ Treatment } & \multirow[b]{2}{*}{ SEM } & \multirow[b]{2}{*}{$P$-value } \\
\hline & $\mathrm{CON}$ & MET & & \\
\hline \multicolumn{5}{|c|}{ Cell adhesion and chemotaxis } \\
\hline SELL & 0.764 & 0.744 & 0.080 & 0.729 \\
\hline$C A D M 1$ & 1.366 & 1.415 & 0.090 & 0.627 \\
\hline$L C P 1$ & 1.009 & 0.940 & 0.060 & 0.323 \\
\hline$C A S P 8$ & 0.826 & 0.697 & 0.120 & 0.010 \\
\hline$C Y B A$ & 1.104 & 0.980 & 0.064 & 0.119 \\
\hline$Z B P 1$ & 0.852 & 0.400 & 0.310 & $<0.001$ \\
\hline$C X C R 2$ & 1.236 & 1.477 & 0.144 & 0.097 \\
\hline \multicolumn{5}{|c|}{ Oxidative stress } \\
\hline$M P O$ & 0.877 & 0.624 & 0.315 & 0.002 \\
\hline SOD1 & 0.799 & 0.702 & 0.281 & 0.100 \\
\hline SOD2 & 0.755 & 0.836 & 0.136 & 0.386 \\
\hline NOS2 & 0.139 & 0.614 & 0.219 & $<0.001$ \\
\hline NFE2L2 & 0.926 & 1.048 & 0.053 & 0.003 \\
\hline \multicolumn{5}{|c|}{ TLR pathway } \\
\hline TLR2 & 1.115 & 1.105 & 0.076 & 0.486 \\
\hline TLR4 & 1.338 & 1.222 & 0.088 & 0.149 \\
\hline$M Y D 88$ & 0.201 & 0.247 & 0.098 & 0.613 \\
\hline$I R A K 1$ & 0.854 & 0.804 & 0.166 & 0.353 \\
\hline TRAF6 & 1.015 & 0.951 & 0.054 & 0.213 \\
\hline NFKB1 & 0.992 & 1.038 & 0.083 & 0.370 \\
\hline NFKBIA & 1.490 & 1.433 & 0.105 & 0.695 \\
\hline$T N F$ & 0.692 & 0.395 & 0.248 & 0.007 \\
\hline$I L 1 B$ & 0.572 & 0.694 & 0.155 & 0.112 \\
\hline SLAMF7 & 0.808 & 0.845 & 0.342 & 0.748 \\
\hline$C T H$ & 0.658 & 0.840 & 0.073 & $<0.001$ \\
\hline$C B S$ & 1.151 & 1.654 & 0.141 & 0.007 \\
\hline$S A H H$ & 0.916 & 0.919 & 0.079 & 0.585 \\
\hline$G C L C$ & 0.732 & 0.768 & 0.245 & 0.408 \\
\hline$G S S$ & 0.876 & 0.804 & 0.064 & 0.114 \\
\hline$G S R$ & 0.926 & 0.701 & 0.075 & 0.009 \\
\hline$G P X 1$ & 0.847 & 0.758 & 0.097 & 0.610 \\
\hline \multicolumn{5}{|l|}{ MicroRNA } \\
\hline MIR125b & 0.880 & 0.809 & 0.152 & 0.314 \\
\hline MIR146a & 1.196 & 1.800 & 0.255 & 0.136 \\
\hline MIR155 & 0.656 & 0.652 & 0.127 & 0.487 \\
\hline MIR223 & 1.123 & 0.953 & 0.080 & 0.521 \\
\hline MIR9 & 1.169 & 0.965 & 0.225 & 0.297 \\
\hline
\end{tabular}

\section{Associations Between Calf Plasma IL-1 $\beta$ at Birth and PMNL mRNA Abundance at Birth}

Significant $(P \leq 0.05)$ positive correlations among plasma IL-1 $\beta$ and PMNL abundance in CON calves were detected for SELL, CADM1, CXCR2, SOD2, TLR2, and TLR4 (Table 5). The only significant correlation in MET calves was between plasma IL-1 $\beta$ and SELL abundance, which was negative.

\section{DISCUSSION}

\section{General}

Previously, we reported hepatic gene transcription data demonstrating that enhancing the maternal supply of Met during late pregnancy was associated with faster maturation of key metabolic pathways, Met metabolism, DNA methylation, and transsulfuration, all of which could benefit the calf's ability to quickly adapt to extrauterine life (Jacometo et al., 2016, 2017). Calves in the present study did not have differences in growth rate, fecal score, and feed intake (Supplemental Table S1; https://doi.org/10.3168/jds.2018-14428) and were free of clinical disease. Thus, although it is possible that the greater prepartal DMI in cows fed MET could have been associated with some of the observed responses in the present study, the lack of effect in terms of colostrum yield and quality (for example) suggest that nutrient supply per se could elicit different physiologic responses. The present study focusing on maternal inflammation status, response of the calf PMNL to LPS challenge, and transcriptional changes 
in PMNL attempts to establish mechanistic linkages whereby the supply of Met and its positive effect on DMI and immune function of the cow (Zhou et al., 2016a) may extend to the calf.

In general, the present data demonstrated links between prepartal inflammatory status of the cow with PMNL mRNA abundance of proinflammatory and host-defense genes in the calf at birth. Furthermore, a maternal effect or interaction with age on expression of key genes related to cell adhesion and chemotaxis, oxidative stress, TLR pathway, Met cycle, and glutathione (GSH) metabolism provide additional evidence (Jacometo et al., 2016, 2017) that enhancing Met supply to the pregnant cow during the last month before calving, either through greater DMI or directly by Met, can elicit preweaning and early postweaning effects on physiologic mechanisms in the calf.

\section{Whole-Blood Response to LPS Challenge}

Using the same in vitro LPS challenge in cows from this study, Vailati-Riboni et al. (2017) revealed that a systemic hyperresponse in IL-1 $\beta$ around parturition, likely arising from oxidative stress, was alleviated by an enhanced Met supply via feeding RPM. Those results demonstrated that blood immune cells can respond to an inflammatory challenge even in a period of immune dysfunction (i.e., the peripartum) and that enhanced Met supply helps control the proinflammatory response. The lower overall basal concentration of IL-1 $\beta$ in the MET calves detected in the present study seems to confirm the cow data from Vailati-Riboni et al. (2017). The response in IL-1 $\beta$ at birth in both CON and MET calves underscored the capacity of circulating immune cells in the newborn calf to respond to an inflammatory challenge, even when plasma cortisol concentration is at its peak (Lee and Kehrli, 1998). The reasons for the marked decrease in the IL- $1 \beta$ response after birth upon LPS challenge in both CON and MET calves are unclear but might be related to temporal dynamics in the profile of endocrine factors and immune cells (Gao et al., 2012). For instance, the profile of $\mathrm{T}$ lymphocyte subsets is associated with plasma concentrations of IL-2, IL-4, and IL-6, which were lower in calves born to cows fed lower energy diet during the last month prepartum (Tao et al., 2012). Other data demonstrated a peak in proliferation rate of blood mononuclear cells (i.e., T cells, B cells, natural killer cells, and monocytes) during the first week of life compared with d 28, 42, and 56 of age (Tao et al., 2012). Overall, the available data suggest an important role of maternal nutrition on neonatal calf immune function and health.

\section{Linkages Among Oxidative Stress, Inflammation, and GSH Synthesis}

An unbalanced cellular redox state is well known to help initiate and promote an inflammatory response, which in turn can result in accumulation of reactive oxygen species (ROS) and reactive nitrogen species (RNS; Chiou et al., 2016). When ROM, RNS, or other inflammatory mediators accumulate, the inducible nitric oxide synthase enzyme triggers the production of large amounts of nitric oxide that can have a cytostatic and cytotoxic effect on pathogenic and nonpathogenic cells (Forstermann and Sessa, 2012). As a counterregulatory mechanism to accumulation of ROM and RNS, the cell depletes its GSH pool, which causes an increase in its synthesis (Shih et al., 2003), in part through activation of the antioxidant transcription factor erythroid-derived factor 2-related factor 2 (NFE2L2; Wakabayashi et al., 2010). Activation or suppression of redox-sensitive signaling (Wink et al., 2011) is closely controlled via the action of NFE2L2, in large part through the inactivation of nuclear factor-kappa B (NFKB1) signaling (Wakabayashi et al., 2010). The resolution of proinflammatory responses induced by ROM, RNS, or proinflammatory molecules is associated with diminished transcription and production of TNF and IL-1 $\beta$. These well-known cellular adaptations in nonruminants would suggest that the greater abundance of NOS2 and NFE2L2 along with the lower abundance of TNF at birth in MET calves reflected a more controlled response of the PMNL (e.g., stronger response with a faster resolution of inflammation). A similar, more controlled response to proinflammatory stimuli was detected in dairy cows supplemented with RPM (Vailati-Riboni et al., 2017).

The lower abundance of GSH reductase $(G S R)$, a key enzyme regulating the availability of reduced GSH (Zhu et al., 2018), along with the greater abundance of cystathionine gamma-lyase $(C T H)$ and cystathionine$\beta$-synthase $(C B S)$ in calves from the MET group suggestive of adaptations in the transsulfuration pathway to generate GSH and potentially control intracellular availability of this antioxidant. Although mRNA abundance of glutamate-cysteine ligase catalytic subunit $(G C L C)$, a rate-limiting enzyme of GSH synthesis, did not differ in CON and MET calves, the fact that its abundance increased 4- to 6 -fold from birth to $50 \mathrm{~d}$ of age underscores the importance of the Met cycle and transsulfuration pathway for PMNL function. Recent in vitro data demonstrated the functionality of these pathways in PMNL from neonatal calves (Abdelmegeid et al., 2017). 
Table 4. Messenger RNA expression after birth and through weaning in polymorphonuclear leukocytes of genes related to cell adhesion and chemotaxis, oxidative stress, Toll-like receptor (TLR) pathway, Met metabolism, glutathione pathway, and microRNA in calves born to dams fed a control diet $(\mathrm{CON})$ or CON supplemented with rumen-protected Met (MET) during the last $21 \mathrm{~d}$ prepartum

\begin{tabular}{|c|c|c|c|c|c|c|c|c|c|}
\hline \multirow[b]{2}{*}{ Item } & \multirow[b]{2}{*}{ Group } & \multicolumn{4}{|c|}{ Day of age } & \multirow[b]{2}{*}{ SEM } & \multicolumn{3}{|c|}{$P$-value ${ }^{1}$} \\
\hline & & 1 & 14 & 28 & 50 & & $\mathrm{~T}$ & $\mathrm{D}$ & $\mathrm{T} \times \mathrm{D}$ \\
\hline \multicolumn{10}{|c|}{ Cell adhesion and chemotaxis } \\
\hline \multirow[t]{2}{*}{ SELL } & MET & 1.096 & 0.955 & 0.783 & 0.853 & 0.080 & 0.033 & $<0.001$ & 0.162 \\
\hline & $\mathrm{CON}$ & 0.760 & 1.131 & 0.612 & 0.666 & & & & \\
\hline \multirow[t]{2}{*}{$C A D M 1$} & MET & 1.678 & 1.207 & 1.245 & 1.575 & 0.090 & 0.021 & $<0.001$ & 0.061 \\
\hline & $\mathrm{CON}$ & 1.874 & 1.718 & 1.313 & 1.775 & & & & \\
\hline \multirow{2}{*}{$L C P 1$} & MET & 1.591 & 0.773 & 0.690 & 0.865 & 0.060 & 0.477 & $<0.001$ & 0.308 \\
\hline & $\mathrm{CON}$ & 1.274 & 0.877 & 0.673 & 0.864 & & & & \\
\hline \multirow[t]{2}{*}{$C A S P 8$} & MET & 1.381 & 1.375 & 1.377 & 2.275 & 0.120 & 0.363 & $<0.001$ & 0.572 \\
\hline & $\mathrm{CON}$ & 1.282 & 1.241 & 1.483 & 1.894 & & & & \\
\hline \multirow[t]{2}{*}{$C Y B A$} & MET & 1.486 & 0.812 & 0.766 & 1.119 & 0.064 & 0.071 & $<0.001$ & 0.137 \\
\hline & $\mathrm{CON}$ & 1.446 & 1.050 & 0.805 & 1.126 & & & & \\
\hline \multirow{2}{*}{$Z B P 1$} & MET & 0.277 & 1.315 & 2.714 & 2.744 & 0.310 & 0.126 & $<0.001$ & 0.053 \\
\hline & $\mathrm{CON}$ & 0.281 & 0.832 & 3.640 & 2.504 & & & & \\
\hline$C X C R 2$ & MET & $1.003^{\mathrm{A}, \mathrm{a}}$ & $0.771^{\mathrm{B}, \mathrm{bc}}$ & $0.649^{\mathrm{b}}$ & $0.915^{\mathrm{ac}}$ & 0.144 & 0.896 & $<0.001$ & $<0.001$ \\
\hline & $\mathrm{CON}$ & $0.774^{\mathrm{B}, \mathrm{b}}$ & $1.113^{\mathrm{A}, \mathrm{a}}$ & $0.594^{\mathrm{c}}$ & $0.828^{\mathrm{b}}$ & & 0.030 & -0.001 & -0.001 \\
\hline Oxidative s & & & & & & & & & \\
\hline$M P O$ & MET & 1.601 & 0.472 & 1.394 & 2.730 & 0.315 & 0.273 & $<0.001$ & 0.262 \\
\hline & $\mathrm{CON}$ & 2.731 & 0.546 & 1.482 & 2.650 & & & & \\
\hline SOD1 & MET & 0.640 & 2.153 & 2.299 & 3.227 & 0.281 & 0.426 & $<0.001$ & 0.240 \\
\hline & $\mathrm{CON}$ & 0.847 & 1.346 & 2.387 & 2.665 & & & & \\
\hline SOD2 & MET & 1.866 & 0.633 & 0.681 & 0.466 & 0.136 & 0.967 & $<0.001$ & 0.084 \\
\hline & $\mathrm{CON}$ & 1.167 & 0.868 & 0.527 & 0.694 & & & & \\
\hline NOS2 & MET & 1.753 & 1.184 & 0.486 & 0.525 & 0.219 & 0.032 & $<0.001$ & 0.840 \\
\hline & $\mathrm{CON}$ & 2.336 & 2.259 & 0.788 & 1.126 & & & & \\
\hline NFE2L2 & MET & 1.120 & 0.883 & 0.776 & 0.752 & 0.053 & 0.313 & $<0.001$ & 0.855 \\
\hline & $\mathrm{CON}$ & 1.108 & 0.880 & 0.720 & 0.676 & & & & \\
\hline TLR pathw & & & & & & & & & \\
\hline TLR2 & MET & $1.608^{\mathrm{a}}$ & $0.557^{\mathrm{B}, \mathrm{c}}$ & $0.662^{\mathrm{c}}$ & $0.911^{\mathrm{b}}$ & 0.076 & 0.018 & $<0.001$ & $<0.001$ \\
\hline & $\mathrm{CON}$ & $1.370^{\mathrm{a}}$ & $0.940^{\mathrm{A}, \mathrm{b}}$ & $0.819^{\mathrm{c}}$ & $0.979^{\mathrm{b}}$ & & & & \\
\hline TLR4 & MET & $1.085^{\mathrm{a}}$ & $0.824^{\mathrm{B}, \mathrm{b}}$ & $0.735^{\mathrm{b}}$ & $0.904^{\mathrm{b}}$ & 0.088 & 0.528 & $<0.001$ & 0.007 \\
\hline & $\mathrm{CON}$ & $0.906^{\mathrm{b}}$ & $1.295^{\mathrm{A}, \mathrm{a}}$ & $0.615^{\mathrm{c}}$ & $0.777^{\mathrm{b}}$ & & & & \\
\hline$M Y D 88$ & MET & 1.445 & 0.926 & 0.833 & 0.987 & 0.098 & 0.523 & $<0.001$ & 0.106 \\
\hline & $\mathrm{CON}$ & 1.101 & 1.035 & 0.761 & 1.031 & & & & \\
\hline$I R A K 1$ & MET & 0.981 & 1.793 & 2.257 & 2.279 & 0.166 & 0.365 & $<0.001$ & 0.403 \\
\hline & $\mathrm{CON}$ & 1.280 & 1.571 & 2.232 & 2.187 & & & & \\
\hline TRAF6 & MET & 0.952 & 1.010 & 0.914 & 0.997 & 0.054 & 0.794 & 0.434 & 0.820 \\
\hline & $\mathrm{CON}$ & 0.988 & 0.979 & 0.923 & 0.949 & & & & \\
\hline NFKB1 & MET & 1.262 & 1.386 & 1.412 & 1.685 & 0.083 & 0.214 & $<0.001$ & 0.756 \\
\hline & $\mathrm{CON}$ & 1.188 & 1.383 & 1.357 & 1.507 & & & & \\
\hline NFKBIA & MET & 0.836 & 0.939 & 0.651 & 0.809 & 0.105 & 0.912 & $<0.001$ & 0.189 \\
\hline & $\mathrm{CON}$ & 0.763 & 1.076 & 0.643 & 0.726 & & & & \\
\hline$T N F$ & MET & 1.706 & 1.270 & 1.616 & 3.685 & 0.248 & 0.917 & $<0.001$ & 0.700 \\
\hline & $\mathrm{CON}$ & 1.789 & 1.331 & 1.900 & 2.820 & & & & \\
\hline$I L 1 B$ & MET & 1.269 & 1.601 & 1.660 & 1.588 & 0.155 & 0.483 & 0.005 & 0.116 \\
\hline & $\mathrm{CON}$ & 1.058 & 1.823 & 1.125 & 1.692 & & & & \\
\hline$S L A M F^{r} 7$ & MET & $0.535^{\mathrm{B}, \mathrm{c}}$ & $2.744^{\mathrm{a}}$ & $3.679^{\mathrm{a}}$ & $3.492^{\mathrm{B}, \mathrm{a}}$ & 0.342 & 0.022 & $<0.001$ & 0.002 \\
\hline & $\mathrm{CON}$ & $1.621^{\mathrm{A}, \mathrm{c}}$ & $2.675^{\mathrm{b}}$ & $3.068^{\mathrm{b}}$ & $5.443^{\mathrm{A}, \mathrm{a}}$ & & & & \\
\hline Methionine & & & & & & & & & \\
\hline $\mathrm{CTH}$ & MET & 1.340 & 1.118 & 1.174 & 1.369 & 0.073 & $<0.001$ & 0.029 & 0.220 \\
\hline & $\mathrm{CON}$ & 1.051 & 1.018 & 1.023 & 1.105 & & & & \\
\hline$C B S$ & MET & $0.607^{\mathrm{B}, \mathrm{c}}$ & $1.875^{\mathrm{A}, \mathrm{b}}$ & $2.397^{\mathrm{A}, \mathrm{a}}$ & $2.272^{\mathrm{a}}$ & 0.141 & 0.471 & $<0.001$ & 0.002 \\
\hline & $\mathrm{CON}$ & $0.728^{\mathrm{A}, \mathrm{c}}$ & $1.524^{\mathrm{B}, \mathrm{b}}$ & $1.858^{\mathrm{B}, \mathrm{a}}$ & $2.180^{\mathrm{a}}$ & & & & \\
\hline$S A H H$ & MET & $1.700^{\mathrm{a}}$ & $0.766^{\mathrm{B}, \mathrm{c}}$ & $0.758^{\mathrm{c}}$ & $1.263^{\mathrm{b}}$ & 0.079 & 0.019 & $<0.001$ & 0.025 \\
\hline & $\mathrm{CON}$ & $1.622^{\mathrm{a}}$ & $1.122^{\mathrm{A}, \mathrm{b}}$ & $0.809^{c}$ & $1.293^{\mathrm{b}}$ & & & & \\
\hline$G C L C$ & MET & 0.530 & 1.798 & 3.109 & 3.222 & 0.245 & 0.686 & $<0.001$ & 0.135 \\
\hline & $\mathrm{CON}$ & 0.651 & 1.568 & 2.520 & 2.787 & & & & \\
\hline$G S S$ & MET & 1.232 & 1.302 & 1.239 & 1.732 & 0.064 & 0.475 & $<0.001$ & 0.487 \\
\hline & $\mathrm{CON}$ & 1.219 & 1.346 & 1.323 & 1.774 & & & & \\
\hline$G S R$ & MET & $1.389^{\mathrm{a}}$ & $0.745^{\mathrm{c}}$ & $0.587^{\mathrm{c}}$ & $0.970^{\mathrm{A}, \mathrm{b}}$ & 0.075 & 0.738 & $<0.001$ & 0.058 \\
\hline & $\mathrm{CON}$ & $1.532^{\mathrm{a}}$ & $0.786^{\mathrm{b}}$ & $0.503^{\mathrm{c}}$ & $0.796^{\mathrm{B}, \mathrm{b}}$ & & & & \\
\hline$G P X 1$ & MET & 1.686 & 0.714 & 0.799 & 1.309 & 0.097 & 0.456 & $<0.001$ & 0.928 \\
\hline & $\mathrm{CON}$ & 1.635 & 0.712 & 1.051 & 1.686 & & & & \\
\hline
\end{tabular}


Table 4 (Continued). Messenger RNA expression after birth and through weaning in polymorphonuclear leukocytes of genes related to cell adhesion and chemotaxis, oxidative stress, Toll-like receptor (TLR) pathway, Met metabolism, glutathione pathway, and microRNA in calves born to dams fed a control diet (CON) or CON supplemented with rumen-protected Met (MET) during the last $21 \mathrm{~d}$ prepartum

\begin{tabular}{|c|c|c|c|c|c|c|c|c|c|}
\hline Item & Group & \multicolumn{4}{|c|}{ Day of age } & SEM & \multicolumn{3}{|c|}{$P$-value ${ }^{1}$} \\
\hline \multicolumn{10}{|l|}{$\overline{\text { MicroRNA }}$} \\
\hline MIR125b & $\mathrm{CON}$ & 1.382 & 1.435 & 2.023 & 2.433 & & & & \\
\hline \multirow[t]{2}{*}{ MIR146a } & MET & 2.764 & 2.144 & 3.580 & 3.167 & 0.255 & 0.631 & $<0.001$ & 0.152 \\
\hline & $\mathrm{CON}$ & 2.651 & 1.767 & 2.775 & 2.048 & & & & \\
\hline MIR223 & $\mathrm{CON}$ & 1.075 & 0.806 & 0.500 & 0.642 & & & & \\
\hline \multirow[t]{2}{*}{ MIR 9} & MET & 1.214 & 2.857 & 7.168 & 5.341 & 0.225 & 0.281 & $<0.001$ & 0.138 \\
\hline & $\mathrm{CON}$ & 4.151 & 5.058 & 5.683 & 4.239 & & & & \\
\hline
\end{tabular}

\footnotetext{
${ }_{\mathrm{A}, \mathrm{B}}$ Means between treatments within time point with different uppercase superscripts differ $(P<0.05)$.

${ }^{\mathrm{a}-\mathrm{c}}$ Means between time points within treatment with different lowercase superscripts $\operatorname{differ}(P<0.05)$.

${ }^{1} \mathrm{~T}=$ treatment; $\mathrm{D}=$ day.
}

\section{PMNL Functional Development}

The treatment $\times$ day interactions that were detected between $\mathrm{d} 1$ and 14 for key genes in the cell adhesion and chemotaxis and TLR pathway are noteworthy. For instance, the gradual decrease in abundance of the C$\mathrm{X}-\mathrm{C}$ motif chemokine receptor 2 (CXCR2) from birth through d 14 of age in MET compared with CON calves could reflect a change in the ability of PMNL to migrate to sites of inflammation (Mehrad et al., 1999). The gradual decrease in abundance of Toll-like receptor 2 (TLR2) and TLR 4 from 1 to $14 \mathrm{~d}$ of age in MET calves seems to underscore the absence of a chronic inflammatory state in the animal, which agrees with a lower basal concentration of IL-1 $\beta$ in those calves. Despite these adaptations seemingly denoting the absence of marked inflammation in both groups of calves, the striking upregulation in the abundance of SLAM family member 7 (SLAMF' $)$ in MET and CON calves between 1 and $14 \mathrm{~d}$ of age (and through $50 \mathrm{~d}$ ) not only confirmed the importance of $\mathrm{T}$ lymphocytes in neonatal calf immunity (Gao et al., 2012) but also suggests activation of monocytes (Kim et al., 2013).

In nonruminants, once they reach steady state, the monocytes circulate in the bloodstream for 1 to $3 \mathrm{~d}$ and effectively provide a supply of macrophages and dendritic cells to peripheral tissues (Serbina et al., 2008). Among the genes measured in the present study, at least in humans and rodents (Serbina et al., 2008), $C X C R 2$ is a chemokine receptor marker whose expression is high in CD14+ monocytes, which account for 80 to $90 \%$ of the total circulating monocyte population. The CD14+ population also expresses high levels of SELL (Serbina et al., 2008). The longitudinal profiles of CXCR2, SELL, and particularly SLAMFY in both
CON and MET calves seem to suggest important developmental adaptations in monocytes. Coupled with the longitudinal increase in mRNA abundance of classical proinflammatory genes (TNF, IL1B, NFKB1, IRAK1) in both CON and MET calves, the 3- to 7-fold increase

Table 5. Significant $(P<0.05)$ correlations among haptoglobin in prepartal ( $-10 \mathrm{~d}$ from parturition) maternal plasma, calf plasma IL-1 $\beta$ concentration at birth, and mRNA abundance in polymorphonuclear leukocytes at birth from calves born to dams fed a control diet (CON) or CON supplemented with rumen-protected Met (MET) during the last $21 \mathrm{~d}$ prepartum

\begin{tabular}{|c|c|c|}
\hline \multirow[b]{2}{*}{ Item } & \multicolumn{2}{|c|}{ Treatment } \\
\hline & $\mathrm{CON}$ & MET \\
\hline \multicolumn{3}{|c|}{ Maternal plasma haptoglobin versus } \\
\hline SELL & $0.713^{*}$ & -0.155 \\
\hline$C A D M 1$ & $0.702^{*}$ & -0.154 \\
\hline$L C P 1$ & $0.778^{*}$ & -0.419 \\
\hline$C Y B A$ & $0.552^{*}$ & $-0.686^{*}$ \\
\hline$C X C R 2$ & $0.689^{*}$ & -0.224 \\
\hline$M P O$ & $0.569^{*}$ & -0.262 \\
\hline SOD2 & $0.521^{*}$ & -0.285 \\
\hline TLR2 & $0.768^{*}$ & -0.423 \\
\hline TLR4 & $0.586^{*}$ & -0.394 \\
\hline$N F K B I A$ & $0.539^{*}$ & $-0.530^{*}$ \\
\hline SLAMFr & $-0.569^{*}$ & -0.092 \\
\hline$G S S$ & $0.780^{*}$ & -0.100 \\
\hline$G S R$ & $0.608^{*}$ & -0.394 \\
\hline$C B S$ & $-0.522^{*}$ & -0.036 \\
\hline$S A H H$ & $0.690^{*}$ & -0.292 \\
\hline$G P X 1$ & 0.197 & $-0.742^{*}$ \\
\hline \multicolumn{3}{|c|}{ Calf plasma IL- $1 \beta$ at birth versus } \\
\hline$S E L L$ & $0.276^{*}$ & $-0.548^{*}$ \\
\hline$C A D M 1$ & $0.573^{*}$ & -0.124 \\
\hline CXCR2 & $0.667^{*}$ & -0.142 \\
\hline SOD2 & $0.602^{*}$ & -0.241 \\
\hline TLR2 & $0.538^{*}$ & 0.014 \\
\hline TLR4 & $0.647^{*}$ & -0.371 \\
\hline
\end{tabular}

*Significant correlation $(P \leq 0.05)$. 
in $S L A M F 7$ abundance between birth and $50 \mathrm{~d}$ of age regardless of maternal diet offers additional support for an important role of monocytes in the young calf.

\section{Regulation of Controlled Apoptosis}

Although data for neonatal calves, to our knowledge, are not available, a controlled inflammatory response is a key feature of the regulation of PMNL apoptosis (Conus et al., 2008; Sagulenko et al., 2016), an idea supported by the lower expression of $C A S P 8$ and $M P O$ in the MET calves and the longitudinal increase in mRNA abundance of Z-DNA binding protein 1 (ZBP1). Apoptosis is well known to be the most common physiologic cell death mechanism of PMNL, helping to prevent the release of cytotoxic contents from dying cells that can damage tissues (Theilgaard-Monch et al., 2006). Both CASP8 and ZBP1 are key mediators of regulated cell death, an essential function during immune cell development that can be triggered by interferons, TLR activation, and other mediators produced during cellular stress, cell damage, or infection (Pasparakis and Vandenabeele, 2015; Kuriakose and Kanneganti, 2018). The longitudinal increase in mRNA abundance of these genes regulating controlled cell death in CON and MET calves is in line with data demonstrating greater CASP8 activity in bovine PMNL as a result of lower cortisol concentration (Burton et al., 2005). Thus, controlled cell death in PMNL during early life of the calf appears to be an important physiologic response.

\section{MicroRNA and PMNL Functional Development}

Among the microRNA evaluated, at least in nonruminants, MIR125b, MIR146a, and MIR9 control the expression of several proinflammatory signals, including TLR4, NFKB1, TNF, and IRAK1; hence, they are considered to diminish the innate inflammatory response (Liu and Abraham, 2013). In contrast, MIR155 enhances the proinflammatory response partly through regulation of $M Y D 88$, and MIR223 helps activate the proinflammatory response of macrophages (Liu and Abraham, 2013). Although there was no treatment or day $\times$ treatment effect for any of the microRNA studied, the significant effect of day on their longitudinal expression is indicative of a functional role in the development of PMNL function during early life. For instance, among the microRNA, the percentage abundance of MIR223 relative to the 5 microRNA studied was more than $99 \%$, underscoring its importance in the calf PMNL. One well-known response of TLR4 activation during inflammation in nonruminant neutrophils and monocytes or dendritic cells (Visintin et al., 2001) is the downregulation of MIR223 abundance, but
MIR223 activation also can control the expression of various TLR signaling components (O'Neill et al., 2011; Liu et al., 2015). The longitudinal decrease in MIR223 over time in both CON and MET calves seems to agree with changes in the expression of monocyte markers (CXCR2, SELL, SLAMF") suggesting the absence of an overt inflammatory response but the existence of a developmental process of immune cells. In that context, it remains to be determined to what extent the longitudinal increases in the abundance of MIR155 (proinflammatory) and MIR125b (antiinflammatory) exert a regulatory role. Although their percentage abundance relative to the microRNA measured accounted for less than $1 \%$, the fact that their known targets include cytokines (TNF) and signaling molecules (MYD88) suggest a role in the coordination of immune cell function (O'Neill et al., 2011).

\section{CONCLUSIONS}

Overall, the data underscore the potential for maternal supply of Met, either through greater DMI or directly by Met, to elicit some changes in offspring PMNL molecular mechanisms that may have a functional role during early postnatal life. The molecular pathways studied encompassing not only immunerelated functions but also Met metabolism are dynamic and likely play a role in the functional capacity of the PMNL in the young animal. The data generated provide some foundations for future studies addressing the development of the calf immune system during early life. Because of the small changes detected at the level of mRNA, generating protein abundance data would be important to better assess the effects of maternal Met on calf innate immune function.

\section{ACKNOWLEDGMENTS}

Carolina Jacometo was supported in part by a fellowship from Coordenação de Aperfeiçoamento de Pessoal de Nível Superior (CAPES, Brasilia, Brazil) from the Brazilian Ministry of Education (Brasilia, Brazil) and by Hatch funds under project ILLU-538-914, National Institute of Food and Agriculture (Washington, DC). Abdulrahman S. Alharthi received a fellowship from King Saud University (Riyadh, Saudi Arabia) to perform his $\mathrm{PhD}$ studies at the University of Illinois (Urbana).

\section{REFERENCES}

Abdelmegeid, M. K., M. Vailati-Riboni, A. Alharthi, F. Batistel, and J. J. Loor. 2017. Supplemental methionine, choline, or taurine alter in vitro gene network expression of polymorphonuclear leuko- 
cytes from neonatal Holstein calves. J. Dairy Sci. 100:3155-3165. https://doi.org/10.3168/jds.2016-12025.

Bertoni, G., A. Ferrari, A. Gubbiotti, and E. Trevisi. 2009. Blood indices calves: Relationship with mother values and changes in the first days of life. Ital. J. Anim. Sci. 8:595-597. https://doi.org/10 .4081/ijas.2009.s2.595.

Blum, J. W. 2006. Nutritional physiology of neonatal calves. J. Anim. Physiol. Anim. Nutr. (Berl.) 90:1-11. https://doi.org/10.1111/j .1439-0396.2005.00614.x.

Burton, J. L., S. A. Madsen, L. C. Chang, P. S. Weber, K. R. Buckham, R. van Dorp, M. C. Hickey, and B. Earley. 2005. Gene expression signatures in neutrophils exposed to glucocorticoids: A new paradigm to help explain "neutrophil dysfunction" in parturient dairy cows. Vet. Immunol. Immunopathol. 105:197-219. https://doi.org/10.1016/j.vetimm.2005.02.012.

Chiou, Y. S., Q. Huang, C. T. Ho, Y. J. Wang, and M. H. Pan. 2016. Directly interact with Keap1 and LPS is involved in the anti-inflammatory mechanisms of (-)-epicatechin-3-gallate in LPSinduced macrophages and endotoxemia. Free Radic. Biol. Med. 94:1-16. https://doi.org/10.1016/j.freeradbiomed.2016.02.010.

Conus, S., R. Perozzo, T. Reinheckel, C. Peters, L. Scapozza, S. Yousefi, and H. U. Simon. 2008. Caspase- 8 is activated by cathepsin D initiating neutrophil apoptosis during the resolution of inflammation. J. Exp. Med. 205:685-698. https://doi.org/10.1084/jem .20072152 .

Everts, R. E., M. R. Band, Z. L. Liu, C. G. Kumar, L. Liu, J. J. Loor, R. Oliveira, and H. A. Lewin. 2005. A 7872 cDNA microarray and its use in bovine functional genomics. Vet. Immunol. Immunopathol. 105:235-245.

Forstermann, U., and W. C. Sessa. 2012. Nitric oxide synthases: Regulation and function. Eur. Heart J. 33:829-837. https://doi.org/10 .1093/eurheartj/ehr304.

Gao, F., Y. C. Liu, Z. H. Zhang, C. Z. Zhang, H. W. Su, and S. L. Li. 2012. Effect of prepartum maternal energy density on the growth performance, immunity, and antioxidation capability of neonatal calves. J. Dairy Sci. 95:4510-4518. https://doi.org/10.3168/jds .2011-5087.

Hill, T. M., H. G. Bateman II, J. M. Aldrich, R. L. Schlotterbeck, and K. G. Tanan. 2008. Optimal concentrations of lysine, methionine, and threonine in milk replacers for calves less than five weeks of age. J. Dairy Sci. 91:2433-2442. https://doi.org/10.3168/jds.2007 -0610 .

Jacometo, C. B., J. S. Osorio, M. Socha, M. N. Correa, F. PiccioliCappelli, E. Trevisi, and J. J. Loor. 2015. Maternal consumption of organic trace minerals alters calf systemic and neutrophil mRNA and microRNA indicators of inflammation and oxidative stress. J. Dairy Sci. 98:7717-7729. https://doi.org/10.3168/jds.2015-9359.

Jacometo, C. B., Z. Zhou, D. Luchini, M. N. Correa, and J. J. Loor. 2017. Maternal supplementation with rumen-protected methionine increases prepartal plasma methionine concentration and alters hepatic mRNA abundance of 1-carbon, methionine, and transsulfuration pathways in neonatal Holstein calves. J. Dairy Sci. 100:3209-3219. https://doi.org/10.3168/jds.2016-11656.

Jacometo, C. B., Z. Zhou, D. Luchini, E. Trevisi, M. N. Correa, and J. J. Loor. 2016. Maternal rumen-protected methionine supplementation and its effect on blood and liver biomarkers of energy metabolism, inflammation, and oxidative stress in neonatal Holstein calves. J. Dairy Sci. 99:6753-6763. https://doi.org/10.3168/ jds.2016-11018.

Kim, J. R., N. C. Horton, S. O. Mathew, and P. A. Mathew. 2013. CS1 (SLAMF7) inhibits production of proinflammatory cytokines by activated monocytes. Inflamm. Res. 62:765-772. https://doi.org/ 10.1007/s00011-013-0632-1.

Kuriakose, T., and T. D. Kanneganti. 2018. ZBP1: Innate sensor regulating cell death and inflammation. Trends Immunol. 39:123-134. https://doi.org/10.1016/j.it.2017.11.002.

Lee, E. K., and M. E. Kehrli Jr.. 1998. Expression of adhesion molecules on neutrophils of periparturient cows and neonatal calves. Am. J. Vet. Res. 59:37-43.
Li, P., Y. L. Yin, D. Li, S. W. Kim, and G. Wu. 2007. Amino acids and immune function. Br. J. Nutr. 98:237-252. https://doi.org/10 $.1017 /$ S000711450769936X.

Liu, G., and E. Abraham. 2013. MicroRNAs in immune response and macrophage polarization. Arterioscler. Thromb. Vasc. Biol. 33:170-177. https://doi.org/10.1161/ATVBAHA.112.300068.

Liu, Y., R. Wang, J. Jiang, B. Yang, Z. Cao, and X. Cheng. 2015. miR223 is upregulated in monocytes from patients with tuberculosis and regulates function of monocyte-derived macrophages. Mol. Immunol. 67:475-481. https://doi.org/10.1016/j.molimm.2015.08 .006 .

Mehrad, B., R. M. Strieter, T. A. Moore, W. C. Tsai, S. A. Lira, and T. J. Standiford. 1999. CXC chemokine receptor-2 ligands are necessary components of neutrophil-mediated host defense in invasive pulmonary aspergillosis. J. Immunol. 163:6086-6094.

Moyes, K. M., J. K. Drackley, D. E. Morin, and J. J. Loor. 2010. Greater expression of TLR2, TLR4, and IL6 due to negative energy balance is associated with lower expression of HLA-DRA and HLA-A in bovine blood neutrophils after intramammary mastitis challenge with Streptococcus uberis. Funct. Integr. Genomics 10:53-61. https://doi.org/10.1007/s10142-009-0154-7.

Naeem, A., J. K. Drackley, J. Stamey, and J. J. Loor. 2012. Role of metabolic and cellular proliferation genes in ruminal development in response to enhanced plane of nutrition in neonatal Holstein calves. J. Dairy Sci. 95:1807-1820. https://doi.org/10.3168/jds .2011-4709.

O'Neill, L. A., F. J. Sheedy, and C. E. McCoy. 2011. MicroRNAs: The fine-tuners of Toll-like receptor signalling. Nat. Rev. Immunol. 11:163-175. https://doi.org/10.1038/nri2957.

Osorio, J. S., P. Ji, J. K. Drackley, D. Luchini, and J. J. Loor. 2013. Supplemental Smartamine M or MetaSmart during the transition period benefits postpartal cow performance and blood neutrophil function. J. Dairy Sci. 96:6248-6263. https://doi.org/10.3168/jds 2012-5790.

Osorio, J. S., E. Trevisi, P. Ji, J. K. Drackley, D. Luchini, G. Bertoni, and J. J. Loor. 2014. Biomarkers of inflammation, metabolism, and oxidative stress in blood, liver, and milk reveal a better immunometabolic status in peripartal cows supplemented with Smartamine M or MetaSmart. J. Dairy Sci. 97:7437-7450. https://doi .org/10.3168/jds.2013-7679.

Pasparakis, M., and P. Vandenabeele. 2015. Necroptosis and its role in inflammation. Nature 517:311-320. https://doi.org/10.1038/ nature14191.

Ranade, R., S. Talukder, G. Muscatello, and P. Celi. 2014. Assessment of oxidative stress biomarkers in exhaled breath condensate and blood of dairy heifer calves from birth to weaning. Vet. J. 202:583-587. https://doi.org/10.1016/j.tvjl.2014.10.025.

Roche, J. R., A. W. Bell, T. R. Overton, and J. J. Loor. 2013. Nutritional management of the transition cow in the 21st centuryA paradigm shift in thinking. Anim. Prod. Sci. 53:1000-1023. https://doi.org/10.1071/AN12293.

Sagulenko, V., K. E. Lawlor, and J. E. Vince. 2016. New insights into the regulation of innate immunity by caspase- 8 . Arthritis Res. Ther. 18:4. https://doi.org/10.1186/S13075-015-0910-0.

Serbina, N. V., T. Jia, T. M. Hohl, and E. G. Pamer. 2008. Monocyte-mediated defense against microbial pathogens. Annu. Rev. Immunol. 26:421-452. https://doi.org/10.1146/annurev.immunol .26 .021607 .090326 .

Shih, A. Y., D. A. Johnson, G. Wong, A. D. Kraft, L. Jiang, H. Erb, J. A. Johnson, and T. H. Murphy. 2003. Coordinate regulation of glutathione biosynthesis and release by Nrf2-expressing glia potently protects neurons from oxidative stress. J. Neurosci. 23:3394-3406.

Tao, S., A. P. Monteiro, I. M. Thompson, M. J. Hayen, and G. E. Dahl. 2012. Effect of late-gestation maternal heat stress on growth and immune function of dairy calves. J. Dairy Sci. 95:7128-7136. https://doi.org/10.3168/jds.2012-5697.

Theilgaard-Mönch, K., B. T. Porse, and N. Borregaard. 2006. Systems biology of neutrophil differentiation and immune response. Curr. Opin. Immunol. 18:54-60. https://doi.org/10.1016/j.coi.2005.11 .010 . 
Vailati-Riboni, M., Z. Zhou, C. B. Jacometo, A. Minuti, E. Trevisi, D. N. Luchini, and J. J. Loor. 2017. Supplementation with rumenprotected methionine or choline during the transition period influences whole-blood immune response in periparturient dairy cows. J. Dairy Sci. 100:3958-3968. https://doi.org/10.3168/jds.2016 $-11812$.

Visintin, A., A. Mazzoni, J. H. Spitzer, D. H. Wyllie, S. K. Dower, and D. M. Segal. 2001. Regulation of Toll-like receptors in human monocytes and dendritic cells. J. Immunol. 166:249-255.

Wakabayashi, N., S. L. Slocum, J. J. Skoko, S. Shin, and T. W. Kensler. 2010. When NRF2 talks, who's listening? Antioxid. Redox Signal. 13:1649-1663. https://doi.org/10.1089/ars.2010.3216.

Wink, D. A., H. B. Hines, R. Y. Cheng, C. H. Switzer, W. Flores-Santana, M. P. Vitek, L. A. Ridnour, and C. A. Colton. 2011. Nitric oxide and redox mechanisms in the immune response. J. Leukoc. Biol. 89:873-891. https://doi.org/10.1189/jlb.1010550.

Zhou, Z., O. Bulgari, M. Vailati-Riboni, E. Trevisi, M. A. Ballou, F. C. Cardoso, D. N. Luchini, and J. J. Loor. 2016a. Rumen-protect- ed methionine compared with rumen-protected choline improves immunometabolic status in dairy cows during the peripartal period. J. Dairy Sci. 99:8956-8969. https://doi.org/10.3168/jds.2016 -10986 .

Zhou, Z., J. J. Loor, F. Piccioli-Cappelli, F. Librandi, G. E. Lobley, and E. Trevisi. 2016b. Circulating amino acids in blood plasma during the peripartal period in dairy cows with different liver functionality index. J. Dairy Sci. 99:2257-2267. https://doi.org/ $10.3168 /$ jds.2015-9805.

Zhou, Z., M. Vailati-Riboni, E. Trevisi, J. K. Drackley, D. N. Luchini, and J. J. Loor. 2016c. Better postpartal performance in dairy cows supplemented with rumen-protected methionine compared with choline during the peripartal period. J. Dairy Sci. 99:8716-8732. https://doi.org/10.3168/jds.2015-10525.

Zhu, Z., S. Du, Y. Du, J. Ren, G. Ying, and Z. Yan. 2018. Glutathione reductase mediates drug resistance in glioblastoma cells by regulating redox homeostasis. J. Neurochem. 144:93-104. https://doi .org/10.1111/jnc. 14250 . 